\title{
HUBUNGAN PENGGUNAAN APD TERHADAP ANGKA KEJADAN INFEKSI NASOKOMIAL PADA PASIEN RAWAT INAP DI RSUD ALIMUDDIN UMAR LIWA KABUPATEN LAMPUNG BARAT
}

\author{
Ismanto Nasim ${ }^{1}$, Andoko $^{2}$, M. Arifki Zainaro ${ }^{3 *}$ \\ ${ }^{1,2,3}$ Program Studi Ilmu Keperawatan, Universitas Malahayati \\ Email Koresponden: m.arifkiz@yahoo.com
}

\begin{abstract}
RELATIONSHIP OF THE USE OF PPE TO THE INCIDENCE OF NASOCOMIAL INFECTION IN INPATIENTS AT ALIMUDDIN HOSPITAL, UMAR LIWA, LAMPUNG BARAT DISTRICT
\end{abstract}

Introduction: After conducting an in-depth survey, it was found that out of 53 medical personnel, it was found that $22(41.5 \%)$ medical personnel did not comply with the use of PPE, and 31 (58.5\%) medical personnel always complied. with the use of PPE.

Purpose: The purpose of this study was to determine the relationship between the use of PPE with the prevalence rate of nosocomial infections in inpatients at Alimuddin Umar Liwa Hospital, West Lampung Regency in 2020.

Methods: The type of research used in this research is quantitative with an analytic design, namely research that explores how and why health phenomena occur using a cross-sectional approach. The population in this study were all nurses at Alimuddin Umar Liwa Hospital, West Lampung Regency, totaling 96 people. The sample in this study amounted to 96 people. In this study the sampling technique used was total sampling.

Results: It is known that in the Alimuddin Umar Liwa Regional Hospital, West Lampung Regency in 2020, most of the respondents used bad PPE, namely 54 respondents (56.3\%) and most of the respondents were at risk of experiencing nosocomial infections, amounting to 50 respondents (52.1\%)

Conclusion: Based on the results of statistical tests, the p-value is 0.000 or $p$ value $<0.05$, which means that there is a relationship between the use of PPE and the prevalence of nosocomial infections in hospitalized patients in the Alimuddin Umar Liwa area. West Lampung District Hospital 2020. The results of this study are expected. so that it becomes an input for Alimuddin Umar Hospital regarding the Relationship between the Use of PPE and the Occurrence of Nasocomial Infection in Inpatients so that with the use of good PPE it is hoped that the incidence of HAl can be resolved properly by giving warnings or even sanctions to nurses if they do not use PPE, as well as more supervision of nurses in using PPE.

Keywords: Use of Personal Protective Equipment \& Incidence Rate of Nasocomial Infection 
INTISARI: HUBUNGAN PENGGUNAAN APD TERHADAP ANGKA KEJADAN INFEKSI NASOKOMIAL PADA PASIEN RAWAT INAP DI RSUD ALIMUDDIN UMAR LIWA KABUPATEN LAMPUNG BARAT

Pendahuluan : Setelah dilakukan survey lebih dalam diketahui dari 53 tenaga medis, diketahui $22(41,5 \%)$ tenaga medis tidak patuh terhadap penggunaan APD, dan $31(58,5 \%)$ tenaga medis selalu patuh dengan penggunaan APD.

Tujuan: tujuan dalam penelitian ini adalah Diketahui Hubungan Penggunaan APD Terhadap Angka Kejadan Infeksi Nasokomial Pada Pasien Rawat Inap Di RSUD Alimuddin Umar Liwa Kabupaten Lampung Barat Tahun 2020.

Metode : Jenis penelitian yang digunakan dalam penelitian ini adalah kuantitatif dengan rancangan analitik yang artinya penelitian yang menggali bagaimana dan mengapa fenomena kesehatan itu terjadi, dengan menggunakan pendekatan cross sectional. Populasi dalam penelitian ini adalah seluruh perawat pelaksanaan Di RSUD Alimuddin Umar Liwa Kabupaten Lampung Barat yang berjumlah 96 orang. Sampel dalam penelitian ini berjumlah 96 orang. Dalam penelitian ini teknik sampling yang digunakan adalah Total Sampling.

Hasil : Diketahui bahwa Di RSUD Alimuddin Umar Liwa Kabupaten Lampung Barat Tahun 2020, sebagian besar responden menggunakan APD kurang baik yang berjumlah 54 responden $(56,3 \%)$ dan sebagian besar responden berisiko mengalami infeksi nasokomial yang berjumlah 50 responden $(52,1 \%)$

Kesimpulan : Berdasarkan hasil uji statistik, didapatkan $\mathrm{p}$-value 0,000 atau $\mathrm{p}$ value $<0,05$ yang artinya terdapat Hubungan Penggunaan APD Terhadap Angka Kejadan Infeksi Nasokomial Pada Pasien Rawat Inap Di RSUD Alimuddin Umar Liwa Kabupaten Lampung Barat Tahun 2020. Hasil penelitian ini diharapkan agar menjadi bahan masukan bagi RSUD Alimuddin Umar tentang Hubungan

Penggunaan APD Terhadap Angka Kejadan Infeksi Nasokomial Pada Pasien Rawat Inap, sehingga dengan penggunaan APD yang baik diharapkan angka kejadian HAls dapat di atasi dengan baik dengan cara memberikan peringatan atau bahkan sanksi kepada perawat jika tidak menggunakan APD, serta lebih melakukan pengawasan terhadap perawat dalam penggunaan APD.

Kata Kunci: Penggunaan Alat Pelindung Diri \& Angka Kejadian Infeksi Nasokomial

\section{PENDAHULUAN}

Pencegahan dan pengendalian infeksi adalah tantangan terbesar dalam tatanan pelayanan kesehatan. Peningkatan biaya untuk mengatasi infeksi yang berhubungan dengan pelayanan kesehatan merupakan keprihatinan besar bagi pasien ataupun profesional layanan kesehatan. Sebab, infeksi biasanya dijumpai dalam seluruh bentuk pelayanan kesehatan. Termasuk infeksi saluran kemih, infeksi pada aliran darah (blood stream infection), pneumonia dan infeksi nasokomial yang sering kali dihubungkan dengan ventilasi mekanis yang tidak memenuhi standar (Rachmawati, 2019).

Infeksi nasokomial merupakan suatu masalah yang nyata diseluruh dunia dan terus meningkat. Contohnya, kejadian infeksi nasokomial berkisar dari terendah sebanyak $1 \%$ dibeberapa Negara Eropa dan Amerika hingga 40\% di beberapa tempat Asia, Amerika Latin dan SubSahara Afrika. Infeksi nasokomial (terdapat di rumah sakit) merupakan fokus penting pencegahan infeksi di semua Negara, namun dinegara berkembang infeksi ini adalah penyebab utama penyakit dan kematian yang dapat dicegah. 
Organism yang menyebabkan infeksi nasokomial biasanya dating dari pasien sendiri (flora endogen), juga dapat diperolah dari kontak dari staf (kontaminasi silang), instrument dan jarum terkontaminasi dan lingkungan (flora eksogen). Karena pasien pada umumnya selalu berpindah-pindah dan waktu rawat di rumah sakit lebih pendek, pasien sering dipulangkan sebelum infeksi menjadi nyata (Saifuddin, 2014).

Menurut World Health Organization (WHO) tahun 2013, presentase infeksi nosokomial di rumah sakit di seluruh dunia mencapai 9\% (variasi 3 - 21\%) atau lebih 1,4 juta pasien rawat inap di rumah sakit seluruh dunia mendapatkan infeksi nosokomial. Menurut survey prevalensi meliputi 55 rumah sakit di 14 negara berkembang pada empat wilayah (Eropa, Mediterania Timur, Asia Tenggara, dan Pasifik Barat) menemukan rata-rata $8,7 \%$ dari seluruh pasien rumah sakit menderita infeksi nasokomial (Saifuddin, 2014).

Angka kejadian HAls di Provinsi Lampung Tahun 2017 mencapai 37\%, dan pada tahun 2018 mengalami peningkatan hingga mencapai $42 \%$, hal ini disebabkan oleh kurangnya sikap serta pengetahuan petugas kesehatan tentang pentingnya penggunaan alat medis yang telah ditetapkan (Profil Provinsi Lampung, 2018).

Menurut data rekam medis RSUD Alimuddin Umar Liwa Lampung Barat, setiap tahun kejadian HAls selalu meningkat $2 \%$, pada tahun 2016 angka HAls mencapai 36\%, tahun 2017 mencapai 38\% dan pada tahun 2018 mencapai 41\%, namun berbeda dengan RS Ryacudu Kotabumi Lampung Utara yang bisa dikatakan setara dengan RSUD Alimuddn Umar, pada tahun 2016 angka HAls mencapai 30\%, tahun 2017 mencapai 32\% dan pada tahun
2018 mencapai 34\%. Tingginya kejadian HAls disebabkan oleh kurangnya kesadaran serta kepatuhan perawat dalam penggunaan APD (Data Rekam Medis RSUD Alimuddin Umar Liwa Lampung Barat, 2018).

Dampak infeksi nasokomial menambahkan ketidakberdayaan fungsional, tekanan fungsional, dan kadang-kadang beberapa kasus akan menyebabkan kondisi kecacatan sehingga menurunkan kualitas hidup. Sebagai tambahan, infeksi nasokomial sekarang juga merupakan salah satu penyebab kematian. Dampak infeksi nasokomial lebih jelas di Negara miskin, terutama yang dilanda HIV/AIDS, karena temuan terakhir membuktikan bahwa pelayanan medis yang tidak aman merupakan faktor penting dalam transmisi suatu penyakit (Saifuddin, 2014).

Beberapa faktor yang menyebabkan risiko infeksi nasokomial pada pasien adalah cara bagaimana praktik keperawatan umum diberikan, rumah sakit komunitas dan pusat kesehatan yang dipimpin oleh dokter umum, jumlah pasien yang dilayani, ketersediaan fasilitas kesehatan, pelayanan spesialis, dukungan pemberian asuhan sekunder serta keterampilan petugas kesehatan dalam menggunakan alat pelindung diri (Rachmawati, 2019).

Alat Pelindung Diri (APD) sangat penting bagi perawat. Setiap hari perawat selalu berinteraksi dengan pasien dan bahaya-bahaya di rumah sakit, hal tersebut membuat perawat beresiko terkena Health care associated Infection (HAls). HAls merupakan infeksi yang terjadi selama dalam proses asuhan keperawatan ataupun selama bekerja di rumah sakit atau di fasilitas pelayanan kesehatan lainnya. Salah satu fasilitas pelayanan kesehatan yang harus lengkap adalah APD, dengan APD 
maka angka kejadian HAls dapat di tangani dengan baik (Jeyaratnam, 2010).

Berdasarkan World Health Organization (WHO) Tahun 2015, penggunaan APD pada perawat hanya mencapai $65 \%$, sedangkan berdasarkan Data Kemenkes RI (2015), penggunaan APD mencapai 53\% dan pada tahun 2016 mencapai $57 \%$. Kurangnya penggunaan APD pada perawat di pengaruhi oleh pengetahuan dan sikap perawat yang kurang positif tentang pentingnya APD. Hal ini dikarenakan kurangnya kesadaran para perawat dan kurangnya pelatihan kesehatan tentang pentingnya penggunaan APD (Kemenkes RI, 2016).

Penggunaan APD salah satu program Pengendalian dan Pencegahan Infeksi (PPI) yang termasuk dalam kewaspadaan isolasi yang disusun oleh Centers for Disease Control and Prevention (CDC). Kewaspadaan isolasi dibagi menjadi 2 pilar yaitu Kewaspadaan Standar (Standard/Universal Precautions) dan kewaspadaan berdasarkan cara transmisi (Transmission based Precautions) (Potter \& Perry, 2012). Kewaspadaan standar yaitu pencegahan dan pengendalian infeksi diterapkan kepada semua pasien yang berprinsip bahwa darah dan cairan tubuh pasien berpotensi menularkan penyakit. Kewaspadaan berdasarkan transmisi merupakan tambahan untuk kewaspadaan standar yaitu tindakan pencegahan dan pengendalian infeksi yang dilakukan setelah jenis infeksi sudah diketahui. Salah satu factor penggunaan APD selalu menurun adalah pengetahuan dan sikap perawat yang kurang positif (Kuntoro, 2010).

Menurut penelitian Sugeng dkk (2014) tentang hubungan penggunaan APD perawat dengan pencegahan infeksi nasokomial di Ruang Rawat Inap Rumah Sakit Paru dr. Ario Wirawan Salatiga Jawa Tengah, menyebutkan bahwa ada hubungan antara hubungan penggunaan APD perawat dengan pencegahan infeksi nasokomial dengan $p$-value 0,01 atau p-value < 0,05 dan menurut penelitian Ita Apriyanti Tentang Hubungan Pengetahuan Dan Sikap Perawat Mengenai APD Dengan Kepatuhan Dalam Menggunakan APD Di RSUD Alimuddin Umar Liwa Kabupaten Lampung Barat Tahun 2017, menyebutkan bahwa Berdasarkan hasil analisis data, diketahui bahwaterdapat hubungan pengetahuan perawat dan sikap dengan kepatuhan dalam menggunakan APD Di RSUD Alimuddin Umar Liwa Kabupaten Lampung Barat Tahun 2018 dengan $\mathrm{p}$-value 0,001 dan 0,020 atau pvalue $<0,05$.

Menurut data prasurvey yang dilakukan Di RSUD Alimuddin Umar Liwa Lampung Barat, peneliti melakukan survey terhadap 4 ruangan yang ada Di RSUD Alimuddin Umar Liwa yaitu Ruang Bedah, Ruang VIP dan VVIP, Ruang Bersalin, dan Ruang Kelas 1, dari 4 ruangan yang ada terdapat jumlah perawat sebanyak 28 orang dan jumlah tenaga bidan sebanyak 25 orang. Setelah dilakukan survey lebih dalam diketahui dari 53 tenaga medis, diketahui 22 (41,5\%) tenaga medis tidak patuh terhadap penggunaan APD, dan 31 (58,5\%) tenaga medis selalu patuh dengan penggunaan APD.

Berdasarkan data yang didapat bahwa Di RSUD Alimuddin Umar Liwa Lampung Barat jarang melakukan pendidikan kesehatan, pelatihan serta kurangnya peran supervisi dalam upaya meningkatkan kepatuhan penggunaan APD yaitu memantau dan mengobservasi penggunaan APD, dan dari tingkat kurangnya kepatuhan penggunaan APD, hampir $30 \%$ pasien post operasi 
yang ada di RSUD Alimuddin Umar berisiko mengalami infeksi nasokomial.

Berdasarkan latar belakang tersebut, penulis tertarik untuk mengetahui "Hubungan Penggunaan APD Terhadap Angka Kejadan Infeksi Nasokomial Pada Pasien Rawat Inap Di RSUD Alimuddin Umar Liwa Kabupaten Lampung Barat Tahun 2020".

\section{Rumusan Masalah}

Berdasarkan masalah dan latar belakang di atas, maka rumusan masalah penelitian di atas adalah "Apakah Ada Hubungan Penggunaan APD Terhadap Angka Kejadan Infeksi Nasokomial Pada Pasien Rawat Inap Di RSUD Alimuddin Umar Liwa Kabupaten Lampung Barat Tahun 2020?”.

\section{METODELOGI PENELITIAN}

Jenis penelitian yang digunakan dalam penelitian ini adalah kuantitatif yaitu penelitian yang berlandaskan filsafat positivisme, digunakan untuk meneliti pada populasi dan sampel tertentu, pengumpulan data menggunakan instrument penelitian, analisis data bersifat kuantitatif statistik dengan tujuan untuk menguji hipotesis (Sulistyaningsih, 2016).

Rancangan dalam penelitian ini menggunakan analitik yang artinya penelitian yang menggali bagaimana dan mengapa fenomena kesehatan itu terjadi, dengan menggunakan pendekatan cross sectional yaitu mengumpulkan faktor risiko/penyebab (variabel bebas) dan efek/akibat (variabel terikat) secara bersamaan (Sulistyaningsih, 2016). Telah dilakukan uji layak etik dengan Nomor Kode Etik: 991/EC/KEP-UNMAL/VII/2020/08 Juli 2020. Waktu penelitian dilakukan pada bulan Juli 2020. Tempat penelitian dilakukan Di RSUD Alimuddin Umar Liwa
Kabupaten Lampung Barat. Populasi dalam penelitian ini adalah seluruh perawat pelaksanaan $\mathrm{Di}$ RSUD Alimuddin Umar Liwa Kabupaten Lampung Barat yang berjumlah 96 orang. Sampel dalam penelitian ini adalah seluruh perawat pelaksanaan Di RSUD Alimuddin Umar Liwa Kabupaten Lampung Barat yang berjumlah 96 orang. Dalam penelitian ini teknik sampling yang digunakan adalah Total Sampling dikarenakan responden yang tersedia $<100$ responden.

\section{HASIL PENELITIAN \\ PEMBAHASAN \\ Hasil Penelitian \\ Karateristik Responden \\ Usia}

DAN

Tabel 1.

Distribusi Frekuensi Usia Perawat Di RSUD Alimuddin Umar Liwa Kabupaten Lampung Barat Tahun 2020

\begin{tabular}{lll}
\hline Usia & $\begin{array}{l}\text { Frekuens } \\
\mathbf{i}\end{array}$ & $\begin{array}{l}\text { Persentas } \\
\text { e (\%) }\end{array}$ \\
$25-32$ & 54 & 56,2 \\
$\begin{array}{l}\text { Tahun } \\
\text { (Dewas }\end{array}$ & \\
a Awal) & \\
$\begin{array}{l}33-43 \\
\text { Tahun }\end{array}$ & 42 & 43,8 \\
(Dewas & & \\
$\begin{array}{l}\text { a Akhir) } \\
\text { Jumlah }\end{array}$ & 96 & 100.0 \\
\hline
\end{tabular}

Berdasarkan tabel 1, diketahui bahwa Di RSUD Alimuddin Umar Liwa Kabupaten Lampung Barat Tahun 2020, sebagian besar responden mempunyai usia 25-32 tahun atau masa dewasa awal yang berjumlah 54 responden $(56,2 \%)$.

\section{Jenis Kelamin}

Tabel 2. Distribusi Frekuensi Jenis Kelamin Perawat Di RSUD Alimuddin Umar Liwa Kabupaten Lampung Barat Tahun 2020 


\begin{tabular}{|c|c|c|}
\hline $\begin{array}{l}\text { Jenis } \\
\text { Kelamin }\end{array}$ & $\begin{array}{l}\text { Frekuen } \\
\text { si }\end{array}$ & $\begin{array}{l}\text { Persenta } \\
\text { se (\%) }\end{array}$ \\
\hline Laki-Laki & 41 & 42.7 \\
\hline $\begin{array}{l}\text { Perempu } \\
\text { an }\end{array}$ & 55 & 57.3 \\
\hline Jumlah & 96 & 100.0 \\
\hline
\end{tabular}
bahwa Di RSUD Alimuddin Umar Liwa Kabupaten Lampung Barat Tahun 2020, sebagian besar responden berjenis kelamin perempuan yang berjumlah 55 responden (57,3\%).

\section{Masa Kerja}

Tabel 3. Distribusi Frekuensi Masa Kerja Di RSUD Alimuddin Umar Liwa Kabupaten Lampung Barat Tahun 2020

\begin{tabular}{lll}
\hline $\begin{array}{l}\text { Masa } \\
\text { Kerja }\end{array}$ & $\begin{array}{l}\text { Frekue } \\
\text { nsi }\end{array}$ & $\begin{array}{l}\text { Persenta } \\
\text { se (\%) }\end{array}$ \\
\cline { 1 - 1 } 5-10Tahun & 64 & 66,7 \\
>10 & 32 & 33,3 \\
$\begin{array}{c}\text { Tah } \\
\text { un }\end{array}$ & & \\
Jumlah & 96 & 100.0 \\
\hline
\end{tabular}

Berdasarkan tabel 3, diketahui bahwa Di RSUD Alimuddin Umar Liwa Kabupaten Lampung Barat Tahun 2020, sebagian besar responden mempunyai masa kerja 5-10 tahun yang berjumlah 64 responden $(66,7 \%)$.

\section{Pendidikan}

Tabel 4. Distribusi Frekuensi Pendidikan Di RSUD Alimuddin Umar Liwa Kabupaten Lampung Barat Tahun 2020

\begin{tabular}{lll}
\hline $\begin{array}{l}\text { Pendidik } \\
\text { an }\end{array}$ & $\begin{array}{l}\text { Frekuen } \\
\text { si }\end{array}$ & $\begin{array}{l}\text { Persenta } \\
\text { se (\%) }\end{array}$ \\
\hline D3 & 49 & 51.0 \\
S1 & 27 & 28.1 \\
Profesi & 20 & 20.8 \\
\hline Jumlah & $\mathbf{9 6}$ & $\mathbf{1 0 0 . 0}$ \\
\hline
\end{tabular}

Berdasarkan tabel 4, diketahui bahwa Di RSUD Alimuddin Umar Liwa Kabupaten Lampung Barat Tahun 2020, sebagian besar responden mempunyai pendidikan D3 yang berjumlah 49 responden $(51,0 \%)$.
Analisis Univariat

Penggunaan APD

Tabel 5.

Distribusi Frekuensi Penggunaan APD Di RSUD Alimuddin Umar Liwa Kabupaten Lampung Barat Tahun 2020

\begin{tabular}{lll}
\hline $\begin{array}{l}\text { Pengguna } \\
\text { an APD }\end{array}$ & $\begin{array}{l}\text { Frekuen } \\
\text { si }\end{array}$ & $\begin{array}{l}\text { Persenta } \\
\text { se (\%) }\end{array}$ \\
\hline Baik & 42 & 43.8 \\
Kurang & 54 & 56.3 \\
Baik & & \\
\cline { 1 - 1 } Jumlah & 96 & 100,0 \\
\hline
\end{tabular}

Berdasarkan tabel 5, diketahui bahwa Di RSUD Alimuddin Umar Liwa Kabupaten Lampung Barat Tahun 2020, sebagian besar responden menggunakan APD kurang baik yang berjumlah 54 responden (56,3\%).

Angka Kejadian Infeksi Nasokomial Tabel 6. Distribusi Frekuensi Kejadian Infeksi Nasokomial Di RSUD Alimuddin Umar Liwa Kabupaten Lampung Barat Tahun 2020

\begin{tabular}{|c|c|c|}
\hline $\begin{array}{l}\text { Kejadian } \\
\text { Infeksi } \\
\text { Nasokomi } \\
\text { al }\end{array}$ & $\begin{array}{l}\text { Frekuen } \\
\text { si }\end{array}$ & $\begin{array}{l}\text { Persenta } \\
\text { se (\%) }\end{array}$ \\
\hline $\begin{array}{l}\text { Tidak } \\
\text { Berisiko }\end{array}$ & 46 & 47.9 \\
\hline Berisiko & 50 & 52.1 \\
\hline Jumlah & 96 & 100,0 \\
\hline
\end{tabular}

Berdasarkan tabel 6, diketahui bahwa Di RSUD Alimuddin Umar Liwa Kabupaten Lampung Barat Tahun 2020, sebagian besar responden berisiko mengalami infeksi nasokomial yang berjumlah 50 responden $(52,1 \%)$.

Analisa Bivariat

Untuk mengetahui Hubungan Penggunaan APD Terhadap Angka Kejadan Infeksi Nasokomial Pada Pasien Rawat Inap Di RSUD Alimuddin Umar Liwa Kabupaten Lampung Barat Tahun 2020, maka digunakan analisa bivariat, yaitu: 


\section{Hubungan Penggunaan APD Terhadap Angka Kejadan Infeksi Nasokomial Pada Pasien Rawat Inap}

Berdasarkan tabel 7, diketahui bahwa Di RSUD Alimuddin Umar Liwa Kabupaten Lampung Barat Tahun 2020, dari 42 responden yang menggunakan APD baik, terdapat 33 responden $(78,6 \%)$ tidak berisiko mengalami infeksi nasokomial dan 9 responden $(21,4 \%)$ berisiko mengalami infeksi nasokomial, sedangkan dari 54 responden yang menggunakan APD kurang baik, terdapat 13 responden $(24,1)$ tidak berisiko mengalami infeksi nasokomial, dan 41 responden $(75,9 \%)$ berisiko mengalami infeksi nasokomial.

Berdasarkan hasil uji statistik, didapatkan p-value 0,001 atau pvalue $<0,05$ yang artinya terdapat Hubungan Penggunaan APD Terhadap Angka Kejadan Infeksi Nasokomial Pada Pasien Rawat Inap Di RSUD Alimuddin Umar Liwa Kabupaten Lampung Barat Tahun 2020. Diketahui nilai OR sebesar 11,564 yang artinya responden yang menggunakan APD kurang baik berisiko 11,564 kali lebih besar untuk mengalami infeksi nasokomial dibandingkan dengan responden yang menggunakan APD secara baik.

\section{Pembahasan Univariat Penggunaan APD}

Berdasarkan hasil penelitian, diketahui bahwa Di RSUD Alimuddin Umar Liwa Kabupaten Lampung Barat Tahun 2020, sebagian besar responden menggunakan APD kurang baik yang berjumlah 54 responden $(56,3 \%)$.

Occupational Safety and Health Administration (OSHA) mendefinisikan APD adalah pakaian khusus atau peralatan yang digunakan oleh karyawan untuk perlindungan diri dari bahan yang menular (Centers for Disease Control and Prevention) (Kuntoro, 2010). APD merupakan suatu alat yang dipakai untuk melindungi diri terhadap bahaya-bahaya kecelakaan kerja, dimana secara teknis dapat mengurangi tingkat keparahan dari kecelakaan kerja yang terjadi. Meskipun tidak menghilangkan ataupun mengurangi bahaya yang ada dengan menggunakan APD (Jeyaratnam, 2010).

Alat pelindung diri bertujuan untuk melindungi dirinya dari sumber bahaya tertentu, yang berasal dari pekerjaan maupun lingkungan pekerjaan dan sebagai usaha untuk mencegah atau mengurangi kemungkinana cedera atau sakit (Jeyaratnam, 2010).. Alat pelindung diri merupakan komponen utama personal precaution beserta penggunaannya yang biasa digunakan perawat sebagai kewaspadaan standar (standard precaution) dalam melakukan tindakan keperawatan (Kuntoro, 2010).

Berdasarkan hasil penelitian dan teori diatas sejalan dengan penelitian Hartono (2014) tentang Hubungan Penggunaan APD dengan Kejadian Infeksi Nasokomial Di RSUD Alimuddin Umar Liwa Kabupaten Lampung Barat Tahun 2014, menyebuBerdasarkan uji statistik, diketahui tkan bahwa ada hubungan yang signifikan antara penggunaan APD dengan Kejadian Infeksi Nasokomial dengan $\mathrm{p}$-value 0,002 atau $p$-value $<0,05$.

Berdasarkan hasil penelitian dan pembahasa diatas, maka menurut peneliti sebagian besar responden mempunyai perilaku penggunaan APD kurang baik, hal ini dikarenakan berdasarkan kuesioner yang telah di 
jawab oleh responden, rata-rata responden setelah melakukan tindakan, responden meletakkan peralatan APD di sembarang tempat, responden menggunakan APD tidak sesuai petunjuknya dan kegunaannya, responden tidak menggunakan baju pelindung pada saat melakukan proses tindakan, responden tidak menggunakan APD sama sekali pada saat melakukan tindakan medis, responden tidak menggunakan APD jika teman-teman yang lain tidak menggunakan APD dan responden akan menggunakan APD jika sudah mendapatkan teguran dari tim survey.

\section{Angka Kejadian Infeksi Nasokomial Berdasarkan hasil penelitian, diketahui bahwa Di RSUD Alimuddin Umar Liwa Kabupaten Lampung Barat Tahun 2020, sebagian besar responden berisiko mengalami infeksi nasokomial yang berjumlah 50 responden $(52,1 \%)$.}

Nasokomial atau HAls Health care associated Infection (HAls) merupakan infeksi yang didapat di rumah sakit dialami oleh seseorang pasien yang dirawat inap di rumah sakit bukan karena infeksi awal yang dialaminya (infeksi yang menyebabkan ia dirawat inap). Umumnya criteria infeksi nasokomial adalah infeksi yang terjadi dalam waktu 48 jam dari sejak dirawat inap di rumah sakit, 3 hari setelah pasien dipulangkan, atau 30 hari pascaoperasi bedah. HAls dapat disebabkan oleh beberapa macam agen penyakit dapatberupa bakteri, virus, jamur, parasit yang merupakan mikroba pathogen penyebab penyakit (Panesar, 2019). Transmisi mikroorganisme di rumah sakit dapat terjadi dengan berbagai cara, bisa lebih dari satu cara. Menurut Saifuddin (2014) ada empat cara terjadinya tranmisi mikroorganisme yaitu:
Penularan secara kontak

Penularan ini dapat terjadi secara kontak langsung, kontak tidak langsung, dan droplet. Kontak langsung terjadi apabila sumber infeksi berhubungan langsung dengan penjamu, misalnya person to person pada penularan terjadi antara pasien ke pasien, petugas ke pasien, pengunjung ke pasien. Kontak tidak langung terjadi apabila penularan membutuhkan objek perantara (biasanya benda mati). Hal ini terjadi karena benda mati tersebut telah terkontaminasi oleh infeksi, misalnya kontaminasi peralatan medis oleh mikroorganisme Penularan melalui common vehicle.

Penularan ini melalui benda mati yang telah terkontaminasi oleh kuman, dan dapat menyebabkan penyakit pada lebih dari satu penjamu. Adapun jenis-jenis common vehicle adalah darah atau produk darah, cairan intravena, obat-obatan dan sebagainya.

Penularan melalui udara, dan inhalasi

Penularan ini terjadi apabila mikroorganisme mempunyai ukuran yang sangat kecil sehingga dapat mengenai penjamu dalam jarak yang cukup jauh, dan melalui saluran pernafasan. Misalnya mikroorganisme yang terdapat dalam sel-sel kulit yang terlepas (staphylococcus) dan mikroorganisme yang dapat hidup di udara seperti bakteri.

Penularan dengan perantara vector Penularan ini dapat terjadi secara eksternal maupun internal. Disebut penularan secara eksternal apabila hanya terjadi pemindahan secara mekanis dari mikroorganisme yang menempel pada tubuh vector, misalnya shigella, dan salmonella oleh lalat. Penularan secara internal 
apabila mikroorganisme masuk ke dalam tubuh vector, dan dapat terjadi perubahan secara biologis.

Berdasarkan hasil penelitian dan teori diatas, sejalan dengan penelitian Yuni Astuti (2014) tentang Faktor-Faktor Yang Berhubungan Dengan Kejadian Infeksi Nasokomial Di RSUD Demang Kabupaten Lampung Tengah Tahun 2014, yang menyebutkan bahwa berdasarkan uji statistik, diketahui bahwa terdapat hubungan faktor-faktor yang berhubungan dengan kejadian infeksi nasokomial (pengetahuan $=0,001, \quad$ sikap $=0,000$ dan penggunaan $A P D=0,002$ ), atau $p$ value $<0,05$.

Berdasarkan hasil penelitian dan pembahasan diatas, maka menurut peneliti sebagian besar responden berisiko mengalami infeksi nasokomial, hal ini dikarenakan berdasarkan lembar observasi diketahui bahwa rata-rata responden mengalami pada area pemasangan infuse intra vena mengalami panas, pada area pemasangan infuse intra vena mengalami kemerahan, pada area pemasangan infuse intra vena mengalami bengkak dan kepala pasien terasa pusing.

\section{Pembahasan Bivariat \\ Hubungan Penggunaan APD Terhadap Angka Kejadan Infeksi Nasokomial Pada Pasien Rawat Inap Berdasarkan hasil penelitian, diketahui bahwa Di RSUD Alimuddin Umar Liwa Kabupaten Lampung Barat Tahun 2020, dari 42 responden yang menggunakan APD baik, terdapat 33 responden $(78,6 \%)$ tidak berisiko mengalami infeksi nasokomial dan 9 responden $(21,4 \%)$ berisiko mengalami infeksi nasokomial, sedangkan dari 54 responden yang menggunakan APD}

kurang baik, terdapat 13 responden $(24,1)$ tidak berisiko mengalami infeksi nasokomial, dan 41 responden $(75,9 \%)$ berisiko mengalami infeksi nasokomial.

Berdasarkan hasil uji statistik, didapatkan $p$-value 0,001 atau $p$ value $<0,05$ yang artinya terdapat Hubungan Penggunaan APD Terhadap Angka Kejadan Infeksi Nasokomial Pada Pasien Rawat Inap Di RSUD Alimuddin Umar Liwa Kabupaten Lampung Barat Tahun 2020. Diketahui nilai OR sebesar 11,564 yang artinya responden yang menggunakan APD kurang baik berpeluang 11,564 kali lebih besar untuk berisiko mengalami infeksi nasokomial dibandingkan dengan responden yang menggunakan APD secara baik.

Dampak infeksi nasokomial menambahkan ketidakberdayaan fungsional, tekanan fungsional, dan kadang-kadang beberapa kasus akan menyebabkan kondisi kecacatan sehingga menurunkan kualitas hidup. Sebagai tambahan, infeksi nasokomial sekarang juga merupakan salah satu penyebab kematian. Dampak infeksi nasokomial lebih jelas di Negara miskin, terutama yang dilanda HIV/AIDS, karena temuan terakhir membuktikan bahwa pelayanan medis yang tidak aman merupakan faktor penting dalam transmisi suatu penyakit (Saifuddin, 2014).

Beberapa faktor yang menyebabkan risiko infeksi nasokomial pada pasien adalah cara bagaimana praktik keperawatan umum diberikan, rumah sakit komunitas dan pusat kesehatan yang dipimpin oleh dokter umum, jumlah pasien yang dilayani, ketersediaan fasilitas kesehatan, pelayanan spesialis, dukungan pemberian asuhan sekunder serta keterampilan petugas kesehatan 
dalam menggunakan alat pelindung diri (Rachmawati, 2019).

Alat Pelindung Diri (APD) sangat penting bagi perawat. Setiap hari perawat selalu berinteraksi dengan pasien dan bahaya-bahaya di rumah sakit, hal tersebut membuat perawat beresiko terkena Health care associated Infection (HAls). HAls merupakan infeksi yang terjadi selama dalam proses asuhan keperawatan ataupun selama bekerja di rumah sakit atau di fasilitas pelayanan kesehatan lainnya. Salah satu fasilitas pelayanan kesehatan yang harus lengkap adalah APD, dengan APD maka angka kejadian HAls dapat di tangani dengan baik (Jeyaratnam, 2010)

Penggunaan APD salah satu program Pengendalian dan Pencegahan Infeksi (PPI) yang termasuk dalam kewaspadaan isolasi yang disusun oleh Centers for Disease Control and Prevention (CDC). Kewaspadaan isolasi dibagi menjadi 2 pilar yaitu Kewaspadaan Standar (Standard/Universal Precautions) dan kewaspadaan berdasarkan cara transmisi (Transmission based Precautions) (Potter \& Perry, 2012). Kewaspadaan standar yaitu pencegahan dan pengendalian infeksi diterapkan kepada semua pasien yang berprinsip bahwa darah dan cairan tubuh pasien berpotensi menularkan penyakit. Kewaspadaan berdasarkan transmisi merupakan tambahan untuk kewaspadaan standar yaitu tindakan pencegahan dan pengendalian infeksi yang dilakukan setelah jenis infeksi sudah diketahui. Salah satu factor penggunaan APD selalu menurun adalah pengetahuan dan sikap perawat yang kurang positif (Kuntoro, 2010)
Menurut penelitian Sugeng dkk (2014) tentang hubungan penggunaan APD perawat dengan pencegahan infeksi nasokomial di Ruang Rawat Inap Rumah Sakit Paru dr. Ario Wirawan Salatiga Jawa Tengah, menyebutkan bahwa ada hubungan antara hubungan penggunaan APD perawat dengan pencegahan infeksi nasokomial dengan $p$-value 0,01 atau $p$-value < 0,05 dan menurut penelitian Ita Apriyanti Tentang Hubungan Pengetahuan Dan Sikap Perawat Mengenai APD Dengan Kepatuhan Dalam Menggunakan APD Di RSUD Alimuddin Umar Liwa Kabupaten Lampung Barat Tahun 2017, menyebutkan bahwa Berdasarkan hasil analisis data, diketahui bahwaterdapat hubungan pengetahuan perawat dan sikap dengan kepatuhan dalam menggunakan APD Di RSUD Alimuddin Umar Liwa Kabupaten Lampung Barat Tahun 2018 dengan $p$-value 0,001 dan 0,020 atau pvalue $<0,05$.

Berdasarkan hasil penelitian dan pembahasan diatas, maka menurut peneliti sebagian besar responden kurang baik dalam menggunakan APD dan sebagian besar juga responden berisiko mengalami infeksi nasokomial, hal ini dikarenakan semakin buruk/kurang baik perilaku penggunaan APD maka semakin tinggi risiko kejadian infeksi nasokomial, namun didalam hasil penelitian diketahui juga bahwa sebagian responden mempunyai perilaku penggunaan APD baik, namun masih ada responden yang berisiko mengalami infeksi nasokomial, hal ini dikarenakan faktor lain yang mempengaruhi, seperti penularan yang terjadi dari pasien satu ke pasien lainnya, serta kurang steril semua alat-alat medis yang akan digunakan untuk tindakan medis. Dalam hasil penelitian 
didapatkan nilai OR mencapai 11,564 yang artinya rata-rata responden yang mengalami infeksi nasokomial dikarenakan kurang baiknya penggunaan APD, sehingga penggunaan APD sangat berpengaruh besar terhadap angka kejadian infeksi nasokomial khususnya di ruang rawat inap RSUD Alimuddin Umar Liwa.

\section{KESIMPULAN DAN SARAN \\ Kesimpulan}

Berdasarkan hasil penelitian diatas, maka kesimpulan dalam penelitian ini adalah sebagai berikut:

a) Diketahui bahwa Di RSUD Alimuddin Umar Liwa Kabupaten Lampung Barat Tahun 2020, sebagian besar responden menggunakan APD kurang baik yang berjumlah 54 responden $(56,3 \%)$

b) Diketahui bahwa Di RSUD Alimuddin Umar Liwa Kabupaten Lampung Barat Tahun 2020, sebagian besar responden berisiko mengalami infeksi nasokomial yang berjumlah 50 responden (52,1\%)

c) Berdasarkan hasil uji statistik, didapatkan pvalue 0,001 atau $p$-value $<$ 0,05 yang artinya terdapat Hubungan Penggunaan APD Terhadap Angka Kejadan Infeksi Nasokomial Pada Pasien Rawat Inap Di RSUD Alimuddin Umar Liwa Kabupaten Lampung Barat Tahun 2020.

\section{Saran}<smiles>[Mg][Mg][Ca]</smiles>

Berdasarkan hasil penelitian diatas, maka saran yang harus peneliti berikan adalah sebagai berikut:

\section{a) Bagi Perawat}

Hasil penelitian ini diharapkan agar dapat dijadikan sebagai bahan informasi kesehatan perawat dengan Penularan Penyakit Nasokomial, sehingga perawat selalu menggunakan APD agar terhindar dari penularan berbagai penyakit yang ada dirumah sakit dengan cara selalu menggunakan APD sesuai dengan petunjuk SOP serta rutin dalam melakukan APD jika akan menjalani tindakan medis, lebih rutin mengikuti pelatihan dan seminar kesehatan tentang pencegahan infeksi nasokomial serta melakukan strerilisasi terhadap alat-alat APD yang sudah digunakan.

b) Bagi RSUD Alimuddin Umar

Hasil penelitian ini diharapkan agar menjadi bahan masukan bagi RSUD Alimuddin Umar tentang Hubungan Penggunaan APD Terhadap Angka Kejadan Infeksi Nasokomial Pada Pasien Rawat Inap, sehingga dengan penggunaan APD yang baik diharapkan angka kejadian HAls dapat di atasi dengan baik dengan cara memberikan peringatan atau bahkan sanksi kepada perawat jika tidak menggunakan APD, lebih melakukan pengawasan terhadap perawat dalam penggunaan APD, diharapkan kepada pihak RSUD agar dapat mengadakan seminar serta pelatihan 


$\begin{array}{lr}\text { kesehatan } & \text { kepada } \\ \text { perawat } & \text { tentang } \\ \text { pentingnya } & \text { penggunaan } \\ \text { APD. } & \end{array}$

\section{DAFTAR PUSTAKA}

Agus, Irianto. (2010). Statistika Konsep, Dasar, Aplikasi, dan Pengembangannya. Jakarta: Kencana Prenada Media Group. Aprina.(2015). Riset Keperawatan. Lampung: Pendidikan Diklat Lampung.

Darmadi. (2018). Infeksi Nosokomial: Problematika dan Pengendaliannya. Jakarta: Salemba medika

Djatmiko, Riswan Dwi. (2016). Keselamatan Dan Kesehatan Kerja. Jakarta : Penerbit Buku Deepublish.

Hartono. (2014). Hubungan Penggunaan APD dengan Kejadian Infeksi Nasokomial Di RS Bumi Waras Bandar Lampung Tahun 2014.

Harrington. (2019). Buku Saku Kesehatan Kerja. Edisi 3. Penerbit EGC. Cetakan I. Jakarta.

Jeyaratnam J., Koh D. (2010). Buku Ajar. Praktek Kedokteran Kerja. Jakarta: EGC.

KEMENKES RI. (2016). Profil Kementerian Kesehatan Republik Indonesia Tahun 2016.

Kuntoro, A. (2010). Buku Ajar Manajemen Keperawatan. Yogyakarta: Nuha Medika.

Mubarak, Wahit lqbal. (2009). Promosi Kesehatan Untuk Kebidanan. Jakarta : Salemba Medika.
Notoatmodjo, Soekidjo. (2010). Metodelogi Penelitian Kesehatan. Jakarta: Rineka Cipta.

Notoatmodjo, Soekidjo. (2010). Promosi Kesehatan dan Ilmu Perilaku Kesehatan. Jakarta: Rineka Cipta.

Riskesdas. (2013). Profil Riset Kesehatan Dasar Tahun 2013.

Rachmawati, Nunung. (2019). Manajemen Patient Safety Konsep \& Aplikasi Patient Safety Dalam Kesehatan. Yogyakarta: PT.Pustaka Baru.

Setiadi. (2017). Konsep dan Penulisan Riset Keperawatan. Yogyakarta : Graha. Ilmu.

Sugiyono. (2016). Metodologi Pendidikan Penelitian. Bandung Alfabeta.

Sulistyaningsih. (2016). Metodologi Penelitian Kebidanan Kuantitatif-Kualitatif Yogyakarta: Graha Ilmu.

Saifuddin. (2014). Asuhan Keperawatan IImu Penyakit Dalam Dan Bedah II. EGC: Jakarta.

Tjokroprawiro. (2014). Pencegahan Infeksi Nasokomial Pada Tenaga Kesehatan. Yogyakarta: Nuha Medika.

Vanessa. (2019). Dalam Rachmawati, Nunung. (2019). Manajemen Patient Safety Konsep \& Aplikasi Patient Safety Dalam Kesehatan. Yogyakarta: PT.Pustaka Baru.

Yuni Astuti. (2014). Faktor-Faktor Yang Berhubungan Dengan Kejadian Infeksi Nasokomial Di RSUD Demang Kabupaten Lampung Tengah Tahun 2014. 